\title{
Aspek Hukum terhadap Perjanjian Pinjam Emas dengan Jaminan Tanah Sawah dalam Masyarakat Pidie
}

\section{Legal Aspects on Gold Loan Agreement with Village Land Guarantee in Pidie Society}

\author{
Sri Hidayani* \& Mahalia Nola Pohan \\ Program Studi Ilmu Hukum, Fakultas Hukum, Universitas Medan Area, Indonesia
}

*Coresponding Email:srihidayani@staff.uma.ac.id

\begin{abstract}
Abstrak
Perkembangan zaman belum merubah beberapa kebiasaan dalam masyarakat Aceh Pidie seperti perjanjian pinjam emas dengan jaminan tanah sawah. Emas menjadi benda yang sangat bernilai untuk masyarakat Aceh. Pada Pasal 1313 Kitab Undang-Undang Hukum Perdata disebutkan suatu perjanjian adalah suatu perbuatan yang mana satu orang atau lebih yang mengikat dirinya terhadap satu orang lain atau lebih. Jaminan adalah sesuatu yang diberikan kreditur untuk menimbulkan keyakinan bahwa debitur akan memenuhi kewajibannya yang dapat dinilai dengan uang yang timbul dari suatu perikatan. Hasil pembahasan yang di lakukan di Desa Raya Paleue, perjanjian pinjam emas dengan jaminan tanah sawah merupakan perjanjian adat yang berlaku sejak turun temurun. Syarat sah suatu perjanjian tertuang dalam Kitab Hukum Undang-undang Perdata. Pemerintah daerah memberikan wewenang terhadap lembaga adat yang bersangkutan untuk menyelesaikan sengketa yang ada seperti yang di tuliskan dalan Qanun No. 10 Tahun 2008.
\end{abstract}

Kata Kunci: Perjanjian, Pinjam Emas, Jaminan Tanah Sawah.

\begin{abstract}
The development of the times has not changed some of the habits in Aceh Pidie society, such as a gold loan agreement with rice fields as collateral.Gold is a very valuable item for the people of Aceh. In Article 1313 of the Civil Code, it is stated that an agreement is an act whereby one or more people bind themselves to one or more other people. A guarantee is something that is given to a creditor to create confidence that the debtor will fulfill an obligation that can be valued in money arising from an engagement. The results of the discussion held in Raya Paleue Village, the gold loan agreement with the guarantee of the fields is a customary agreement that has been valid from generation to generation. The legal requirements for an agreement are contained in the Civil Code. The local government gives the authority to the customary institution concerned to resolve existing disputes as written in Qanun No. 10 of 2008.
\end{abstract}

Keywords: Agreement, Gold Borrowing, Village Guarantee

How to Cite: Hidayani, S. \& Pohan, M.N. (2020). Abstrak Aspek Hukum terhadap Perjanjian Pinjam Emas dengan Jaminan Tanah Sawah dalam Masyarakat Pidie. Jurnal Mercatoria. 13 (2): 205-215. 


\section{PENDAHULUAN}

Manusia adalah salah satu dari dari bagian subyek hukum baik itu warga negara ataupun dengan orang asing dengan tak memandang agama atau kebudayaannya (Soeroso, 1992). Subjek hukum adalah segala sesuatu yang dapat mempunyai hak dan kewajiban menurut hukum (Arifin, 2014).

Manusia mempunyai hak-hak dan kewajiban-kewajiban untuk melakukan suatu tindakan hukum seperti mengadakan perjanjian-perjanjian, perkawinan, wasiat dan sebagainya. Dalam hukum seorang yang mempunyai hak milik atas sesuatu benda kepadanya diizinkan untuk menikmati hasil dari benda miliknya (Kansil, 1986). Berlakunya manusia sebagai pembawa hak, mulai dari saat dia dilahirkan dan berakhir pada saatnya dia meninggal dunia bahkan seorang anak yang masih dalam kandungan ibunnya dapat dianggap sebagai pembawa hak atau dianggap telah lahir jika kepentingannya memerlukan untuk menjadi ahli waris.

Setiap manusia tidak terkecuali dapat memiliki hak-hak akan tetapi didalam hukum tidaklah semua orang diperbolehkan bertindak sendiri didalam melaksanakan hak-haknya itu. Dalam masyarakat pedesaan unsur kepercayaan satu sama lain dan sifat tolong menolong masih dipegang teguh sehingga masih berlaku hingga sekarang. Tidak jarang mereka juga melakukan perikatan dengan cara sederhana seperti sebuah perjanjian pinjam emas dengan jaminan tanah sawah.

Hal ini sering kita jumpai pada masyarakat pedesaan seperti masyarakat Aceh Pidie dimana mereka menggunakan emas dalam proses perjanjian pinjam meminjam dengan jaminan tanah pertanian. Perikatan adalah suatu kaidahkaidah hukum yang mengatur antara hubungan subjek hukum yang satu dengan subjek hukum yang lainnya dalam suatu bidang tertentu terhadap harta kekayaan, dimana dalam subjek hukum yang satu berhak atas suatu prestasi sedangkan subjek hukum yang lainnya berkewajiban untuk memenuhi prestasinya (Tutik, 2006). Sistem pengaturan hukum jaminan terbuka adalah sistem pengaturan bahwa orang dapat mengadakan perjanjian apapun juga tentang jaminannya sesuai dengan Kitab Undang-Undang Hukum Perdata dan tidak menentang ketertiban umum yang berlaku dalam masyarakat (Salim, 2004).

Jaminan tanah sawah yang diberikan oleh peminjam merupakan 
jaminan yang telah diatur di dalam hukum jaminan. Jaminan merupakan aset pihak peminjam yang diberikan kepada pemberi pinjaman jika peminjam tidak dapat mengembalikan pinjamannya maka aset yang dijaminkan dapat dimiliki oleh orang yang memberikan pinjaman.

Sistem pengaturan hukum jaminan dibagi dua macam yaitu sistem tertutup dan sistem terbuka. Sistem pengaturan hukum terbuka adalah orang yang tidak dapat mengadakan hak-hak jaminan baru, selain yang telah ditetapkan dalam undang-undang. Pada perjanjian pinjam emas dengan jaminan tanah sawah sering disebut masyarakat Aceh Pidie adalah gala atau gadai adat. Transaksi seperti ini biasanya terdapat di seluruh Indonesia.

Gadai adalah hubungan hukum antara seseorang dengan tanah kepunyaan orang lain, yang telah menerima uang gadai dari padanya (Supriadi, 2008). Gadai-menggadai menurut ketentuan hukum adat umumnya mengandung unsur exploistasi, karena hasil yang diterima oleh pemegang gadai dari tanah yang bersangkutan setiap tahunnya umum jauh lebih besar jika dibandingkan dengan apa yang merupakan Bungan yang layak dari uang gadai yang diterima pemilik tanah.
Umumnya kedudukan ekonomi pemegang gadai lebih kuat dibandingkan dengan pemilik tanah.

Jadi yang menjadi masalahmasalah pokok di dalam tulisan ini adalah bagaimana bentuk dan tujuan perjanjian pinjam emas jaminan dengan tanah sawah dalam masyarakat Aceh Pidie, bagaimana proses terjadinya perjanjian pinjam emas dengan jaminan tanah sawah dalam masyarakat Aceh Pidie, bagaimana syarat sah perjanjian pinjam emas dengan jaminan tanah sawah dalam masyarakat Aceh Pidie, serta bagaimana hambatan dalam pengembalian emas, bentuk sengketa, cara penyelesaian sengketa dan hambatan dalam penyelesaian sengketa dalam perjanjian pinjam emas dengan jaminan tanah sawah dalam masyarakat Aceh Pidie.

\section{METODE PENELITIAN}

Jenis penelitian adalah penelitian hukum normatif. Penelitian hukum normatif adalah penelitian yang mengkaji norma-norma yang berlaku meliputi undang-undang yang mempunyai relevansi dengan permasalahan sebagai bahan hukum sumbernya (Soerjono Soekanto dan Sri Mamudji, 2001). Sifat penelitian deskriptif analitis yaitu analisis data yang dilakukan tidak keluar 
dari lingkup permasalahan dan berdasarkan teori atau konsep yang bersifat umum diaplikasikan untuk menjelaskan tentang seperangkat data, atau menunjukkan komparasi atau hubungan seperangkat data dengan seperangkat data yang lain (Sunggono, 2011). Adapun teknik pengumpulan data dilakukan dengan cara penelitian pustaka dan penelitian kelapangan.

Metode ini dengan melakukan penelitian terhadap berbagai sumber bacaan tertulis dari para sarjana yaitu buku-buku teori tentang hukum, majalah hukum, jurnal-jurnal hukum dan juga bahan-bahan kuliah serta peraturanperaturan terkait dan Metode lapangan adalah dengan langsung mengadakan penelitian di kampung Raya Paleue Kecamatan Simpang Tiga Kabupaten Pidie (Soekanto, 2007).

\section{HASIL DAN PEMBAHASAN}

Bentuk dan Tujuan Perjanjian Pinjam Emas dengan Jaminan Tanah Sawah

Berdasarkan hasil wawancara dengan Bapak Zakaria A B Selaku Keuchik (Kepala Desa) Raya Paleue bentuk perjanjian pinjam emas dengan jaminan tanah sawah adalah perjanjian tertulis. Perjanjian dilakukan dengan menggunakan akta dibawah tangan. Akta dibawah tangan adalah suatu akta yang dibuat dan ditandatangani oleh pihak saja dengan tanpa bantuan seorang penjabat umum atau akta yang dibuat oleh atau di hadapan penjabat umum yang tidak berwenang. Perjanjian pembebanan dalam bentuk lisan, biasanya dilakukan dalam kehidupan masyarakat pedesaan, masyarakat yang satu membutuhkan pinjaman uang kepada masyarakat, yang ekonominya yang lebih tinggi. Biasanya pinjaman itu cukup dilakukan secara lisan. Seseorang yang ingin mendapatkan pinjaman cukup menyerahkan tanah. Setelah tanah diserahkan, maka uang pinjaman diserahkan kreditor kepada debitur.

Ketentuan mengenai akta dibawah tangan dapat ditemukan dalam Pasal 1874 KUHPerdata dalam ayat 1 menyatakan sebagai tulisan-tulisan dibawah tangan, akta-akta yang ditandatangani dibawah tangan, suratsurat, register-register, surat-surat urusan rumah tangga, dan lain-lain tulisan yang dibuat tanpa perantara seorang pegawai umum.

Dalam undang-undang ditentukan bahwa akta bahwa tangan dapat dijadikan sebagai alat bukti yang lengkap sepanjang tanda tangan dalam akta tersebut diakui keasliannya sedangkan 
Sri Hidayani \& Mahalia Nola Pohan, Abstrak Aspek Hukum terhadap Perjanjian Pinjam Emas dengan Jaminan Tanah Sawah dalam Masyarakat Pidie

apabila tanda tangan atau tulisannya dipungkiri, maka pemeriksaan kepalsuan harus diselesaikan terlebih dahulu (Muhammad, 1981). Pada Pasal 1878 KUHPerdata terdapat kekhususan akta dibawah tangan yaitu akta harus seluruhnya ditulis dengan tangan oleh sipenandatangan sendiri, atau setidaktidaknya, selain tanda tangan, harus ditulis dengan tangannya si penandatangan adalah suatu penyebutan yang memuat jumlah atau besarnya barang/uang yang terutang.

Dengan kekhususan ini dimaksudkan apabila ketentuannya tidak dipenuhi, maka akta tersebut hanya sebagai suatu permulaan pembuktian dengan tulisan. Tentang pengakuan tanda tangan apabila dikemukakan dimuka hakim, menurut Wirjono Prodjodikoro pengakuan itu berbunyi: tanda tangan saya da nisi dituliskan adalah benar (Prodjodikoro, 2011). Syarat akta bawah tangan terdapat syarat formil dan materil, syarat formil berkenaan dengan bentuk tertulis/tulisan, dibuat secara benar, ditandatangani dan mencantumkan tanggal dan tempat penandatanganan, sedangkan syarat materil mengenai keterangan yang tercantum didalamnya berisikan persetujuan tentang perbuatan hukum dan hubungan hukum (Prodjodikoro, 2011).

Berdasarkan hasil wawancara dengan Bapak Zakaria A B Selaku Keuchik (Kepala Desa) Raya Paleue Masyarakat Aceh adalah masyarakat yang sangat menjunjung tinggi harga diri dari setiap anggota keluarganya. Atas dasar inilah banyak sekali keperluan yang mengharuskan mereka penuhi. Salah satunya dalam mengadakan pesta perkawinan. Pihak lelaki yang menjadikan emas sebagai mahar harus menyediakan emas dalam jumlah banyak.

Sedangkan pihak perempuan yang mengadakan pesta harus menyimpan emas yang kemudian sebagai simpanan jika pada saat pesta emas yang dibawakan laki-laki tidak cukup dalam mencukupi kebutuhan pesta. Selain pesta pernikahan, emas hasil pinjaman dari menggadaikan sawah juga digunakan sebagai modal membuka usaha, serta biaya pendidikan di Kota.

\section{Proses Terjadinya Perjanjian Pinjam}

\section{Emas dengan Jaminan Tanah Sawah}

Perjanjian pinjam emas dengan jaminan tanah sawah dalam masyarakat Aceh Pidie terjadi dengan sangat sederhana. Dimana ada kebutuhan mendadak yang membutuhkan uang dalam jumlah banyak dalam waktu 
singkat maka akan mendatagi orang yang dianggap mempunyai ekonomi lebih kuat. Pihak yang akan meminjam emas harus menawarkan sawah sebagai jaminan (Usman, 2016). Jika sudah ada persetujuan oleh kedua belah pihak maka segeralah dibuat surat keterangan gadai atau gala. Didalam selembar kertas perjanjian para pihak saling mengikat dirinya. Surat perjanjian diberi judul "surat keterangan jual angkat" atau "gadai/gala.

Praktek perjanjian pinjam emas dengan jaminan tanah sawah sudah dikenal dengan istilah gadai atau gala oleh masyarakat setempat. Istilah Jual Angkat digunakan hanya untuk mengindari riba. Tetapi ada beberapa daerah yang masih menggunakan istilah gadai atau gala. Judul surat perjanjian bisa ditentukan oleh pihak yang melakukan perjanjian dengan judul gadai atau gala.

Gadai tanah adalah penyerahan tanah milik kedalam kekuasaan pihak lain, yang telah memberikan uang kepada pemilik tanah, sampai uang gadai itu dikembalikan atau ditebus (Ruchyat, 1983). Dalam hal gadai atau gala ini justru pemilik tanah merupakan pihak yang lemah, karena ia terdesak sekali untuk keperluan konsumtif. Selama proses gadai berlangsung tanah dikuasai oleh pemegang hak jaminan tanah sawah. Sebelum tanah ditebus hal itu akan terus terjadi.

\section{Syarat Sah Perjanjian Pinjam Emas dengan Jaminan Tanah Sawah}

Syarat Sah Perjanjian Pinjam Emas dengan Jaminan Tanah Sawah, terdiri dari:

1. Adanya kesepakatan kedua belah pihak. Dalam suatu perjanjian harus mempunyai kemauan yang bebas untuk mengikatkan dirinya dan kemauan itu harus dinyatakan. Pernyataan dapat dilakukan dengan tegas atau diam-diam (Subekti, 2014). Kemauan yang bebas sebagai syarat pertama untuk suatu perjanjian yang sah dianggap tidak ada jika perjanjian itu telah terjadi karena paksaan, kekhilafan atau penipuan. Dalam hukum adat, kesepakatan bisa dilakukan secara lisan tanpa adanya tulisan. Kesederhanaan dalam kesepakatan adalah bukti dari interaksi yang diperoleh dari kebiasaan berbaik sangka kepada sesama. Namun di zaman sekarang kesepakatan secara lisan sudah tidaklah cukup. (Hasil Wawancara Bapak Zakaria A B 
Sri Hidayani \& Mahalia Nola Pohan, Abstrak Aspek Hukum terhadap Perjanjian Pinjam Emas dengan Jaminan Tanah Sawah dalam Masyarakat Pidie

Selaku Keuchik (Kepala Desa) Raya Paleue). Dalam perjanjian kesepakatan itu diwujudkan dalam selembar kertas yang dibuat oleh kedua belah pihak dengan dilengkapi oleh tanda tangan sebagai bukti nyata dari kesepakatan tanpa ada paksaan dari pihak manapun. Karena sifat amanah yang merupakan ajaran dari islam sudah mulai hilang.

2. Kecakapan untuk membuat suatu perjanjian. Pasal 1329 Kitab Undangundnag Hukum Perdata mengatakan bahwa setiap orang adalah cakap untuk membuat perikatan-perikatan, jika ia oleh undang-undang tidak dinyatakan tak cakap.

3. Suatu hal tertentu. Suatu hal tertentu merupakan pokok perjanjian, merupakan prestasi yang perlu dipenuhi dalam suatu perjanjian, merupakan obyek perjanjian. Seperti dalam perjanjian pinjam emas dengan jaminan tanah sawah bahwa jenis emas harus disebutkan seperti emas London yang tertulis secara jelas dalam surat perjanjian, luas tanah sawah harus disebutkan dengan jelas, dan yang penting ialah harga pinjam tidak boleh melebihi dari harga jual tanah (emas $\pm 1 / 3$, 1/2 dari harga jual tanah pada saat perjanjian diadakan). (Hasil
Wawancara Bapak Zakaria A B Selaku Keuchik (Kepala Desa) Raya Paleue).

4. Sebab yang halal. Pasal 1336 menyebutkan jika tidak dinyatakan sesuatu sebab, tetapi ada suatu sebab yang halal, ataupun jika ada suatu sebab lain, dari pada yang dinyatakan perjanjiannya namun demikian adalah sah. Keabsahan suatu perjanjian digantungkan pada sebab yang halal, walaupun hal itu tidak dicantumkan secara jelas dalam perjanjian. Dan Pasal 1337 Suatu sebab adalah terlarang, apabila dilarang oleh undang-undang, atau apabila berlawanan dengan kesusilaan baik atau ketertiban umum. Sebab yang halal adalah perjanjian yang dibuat tidak melanggar undang-undang yang ada. Karena perjanjian ini juga terjadi dalam masyarakat yang masih memegang teguh adat-adat istiadat maka perjanjian diindahkan sesuai dengan ketertiban, dan kebiasaan masyarakat setempat agar tidak dianggap menyeleweng yang nantinya akan mudah memenuhi hak-hak dan kewajiban yang berlaku sesuai dengan ketentuan daerah setempat. (Hasil Wawancara Bapak 
Zakaria A B Selaku Keuchik (Kepala

Desa) Raya Paleue).

\section{Hambatan Pengembalian Emas, Bentuk Sengketa dan Cara Penyelesaiannya}

Hambatan pengembalian emas, bentuk sengketa dan cara penyelesaiannya, terdiri dari:

a. Hambatan Pengembalian Emas

Hambatan dalam pengembalian biasanya terjadi ketika harga emas sudah tidak sama ketika si peminjam meminjam. Harga emas yang sudah jauh berbeda ini menjadi salah satu alasan utama bagi peminjam.

Adapun yang menyebabkan harga emas naik adalah:

1) Nilai tukar US Dollar secara umum, kolerasi negatif tercipta dari hubungan nilai tukar US Dolar dengan harga emas yang sedang berlaku saat itu. Bila dollar Amerika menguat maka harga emas jadi turun.

2) Jumlah produksi emas di dunia semakin susahnya emas ditambang, maka harga emas dipasaran akan naik karena kelangkaan stoke mas. Apalagi bila permintaan akan emas malah semakin meningkat, sehingga penambang harus menggali semakin dalam.

3) Kenaikan permintaan dari pihak industry perhiasan didunia ini masih berhubungan dengan faktor nomor dua. Misalnya, 54 persen permintaan emas berasal dari industri perhiasan didunia, seperti yang terdapat di India, Tiongkok dan Amreka Serikat. Sementara itu, 12 persennya berasal dari industri peralatan medis dan elektronik. Fakta ini dilansir oleh World Gold Council dan The London Bullion Market Association. Tidak heran bila harga emas naik.

4) Beberapa bank sentral dunia memonopoli pembelian emas Beberapa bank sentral di dunia, seperti: The Federal Reserve System (di Amerika Serikat), Bundesbank (di Jerman), dan European Central Bank (ECB) telah melakukannya. Tidak hanya uang kertas, mereka juga telah lama memonopoli pembelian emas.Jangan heran bila harga emas semakin naik dan emas semakin langka. Karena sudah lama 'colong start', cadangan emas mereka pun lebih banyak. Hal ini juga dilansir oleh World Gold Council. 
Sri Hidayani \& Mahalia Nola Pohan, Abstrak Aspek Hukum terhadap Perjanjian Pinjam Emas dengan Jaminan Tanah Sawah dalam Masyarakat Pidie

5) Isu politik, seperti resesi global, perselisihan antar negara, atau perang dapat membuat harga emas naik Salah satunya adalah isu Brexit (keluarnya Inggris Raya dari Uni Eropa akibat hasil jajak pendapat terakhir yang terkait dengan Uni Eropa pada Juni 2016). Akibatnya, para investor diserang panik dan mulai memborong emas dalam jumlah besar. (Usman, 2016).

b. Bentuk Sengketa Masyarakat Aceh tidak terlepas dari hukum islam,

Kebiasaan yang mereka lakukan sehari-hari sudah pasti dipengaruhi oleh islam. Dikarenakan hukum adat adalah hukum yang tertua setelah hukum islam maka segala yang berhungan dengan adat berbaur dengan hukum islam.

Hukum islam baru dikenal di Indonesia setelah agama Islam disebarkan di tanah air (Ali, 2014). Jika ada masalah mereka akan mengutamakan musyawarah. Sengketa yang ada hanyalah kesalapahaman antara pihak pertama dan pihak kedua. Adapun bentuk sengketanya adalah:

1) Jenis emas yang dikembalikan tidak sesuai dengan yang jenis emas waktu peminjaman,

2) Peralihan hak Gadai/Gala tanpa sepengetahuan dari pihak kedua.
3) Menyalahgunakan hak Gadai/Gala sawah.

Dalam Pasal 1754 Kitab Undangindang Hukum Perdata menjelaskan bahwa "Pinjam meminjam ialah perjanjian dengan mana pihak yang satu memberikan kepada pihak yang lain suatu jumlah tertentu barang-barang yang menghabis karena pemakaian, dengan syarat bahwa pihak yang belakangan ini yang akan mengembalikan sejumlah yang sama dari macam dan keadaan yang sama pula".

Pasal 1758 menyatakan "Bahwa jika yang dipinjamkan itu berupa batangbatangan mas atau perak atau lain-lain barang perdagangan, maka betapa pun naik atau turun harganya, si berutang senantiasa harus mengembalikan jumlah yang sama berat dan sama mutunya, dan tidaklah diwajibkan memberi lebih dari pada itu". Dari penjelasan dua pasal ini menerangkan bahwa apa yang di pinjamkan harus dikembalikan seperti keadaan sebelumnya tanpa kekurangan suatu apapun.

Terkadang hal seperti ini tidak diindahkan oleh beberapa orang. Mereka tidak amanah sepeti yang dianjurkan dalam hukum islam.

c. Penyelesaian Sengketa Gadai/gala bukan merupakan hal yang baru lagi dalam masyarakat aceh Pidie 
Praktek yang sudah berlangsung turun temurun ini dilakukan sesuai dengan syariat islam serta ketentuan adat dengan tidak melanggar hukum Negara yang berlaku.

Penyelesaian sengketa terhadap perjanjian pinjam emas dengan jaminan tanah sawah biasanya akan diselesaikan secara adat oleh lembaga adat. Dalam Qanun Aceh Nomor 10 tahun 2008 menyebutkan Lembaga adat adalah suatu organisasi kemasyarakatan adat yang dibentuk oleh suatu masyarakat hukum adat tertentu mempunyai wilayah tertentu dan mempunyai harta kekayaan sendiri serta berhak dan berwenang untuk mengatur dan mengurus serta menyelesaikan hal-hal yang berkaitan dengan adat Aceh.

Dalam menyelesaikan sengketa lembaga adat yang bersangkutan akan memanggil pihak-pihak yang melakukan perjanjian, saksi-saksi, dan juga masyarakat lainnya yang sekiranya pendapatnya diperlukan dalam sengketa yang ada. Biasanya penyelesaian sengketa di adakan di meunasah Gampong (Kampung). Setelah itu akan diadakan musyawarah dengan mendengarkan pendapat dari masingmasing pihak. Pendapat yang ada akan dipertimbangkan secara bijaksana sehingga keputusan secara damai dapat menjunjung rasa keadilan diantara pihakpihak yang bersangkutan sehingga tidak ada pihak yang merasa dirugikan oleh putusan tersebut. Setelah itu lembaga adat akan membuat pernyataan damai secara tertulis antara kedua belah pihak agar tidak terjadi sengketa dilain hari. Menurut Peraturan Mentri Pertanian dan Agraria Nomor 20 Tahun 1963 tentang Penyelesaian Masalah Gadai sudah dijelaskan dalam Pasal 4 ayat 1 hurf a b dan c, serta ayat 2 .

\section{SIMPULAN}

Bentuk perjanjian pinjam emas dengan jaminan tanah sawah adalah bentuk perjanjian secara tertulis dan dibuat dibawah tangan yang biasanya disebut dengan surat Gampong (Kampung). Emas yang biasanya dipinjam biasanya akan digunakan untuk keperluan pesta pernikahan, biaya kesehatan, biaya pendidikan, dan lainnya. Peminjaman emas dengan jaminan tanah sawah dilakukan dengan proses sederhana yaitu tidak mempersulit pihak yang akan meminjam karena masyarakat Aceh Pidie menganggap tolong-menolong antar sesama. Syarat sah perjanjian dilaksanakan sesuai dengan Pasal 1320 Kitab Undang-undang Hukum Perdata, 
Sri Hidayani \& Mahalia Nola Pohan, Abstrak Aspek Hukum terhadap Perjanjian Pinjam Emas dengan Jaminan Tanah Sawah dalam Masyarakat Pidie

selain syarat sah yang sudah ditentukan secara hukum maka dalam perjanjian pinjam emas ialah Pinjaman emas didapat jika orang yang ingin meminjam untuk kebutuhan mendadak mempunyai tanah sawah yang masih produktif, emas yang di pinjam bisa 1/3, 1/2 dari harga jual tanah sawah. Harga emas yang makin lama makin tinggi membuat pihak yang meminjam emas kesulitan membeli dengan jenis dan mutu yang sama. Namu terhadap pengembalian sudah diatur di dalam Pasal 1758 Kitab Undang-undang Hukum Perdata. Tidak banyak bentuk sengketa yang ada melainkan pada jenis yang dikembalikan, pengalihan gadai tanah sawah yang tanpa sepengetahuan pemiliknya serta menyalah gunakan hak yang sebagai penerima gadai. Penyelesaian sengketa dilakukan secara damai dengan cara musyawarah oleh lembaga adat yang bersangkutan. Hambatan dalam penyelesaian sengketa adalah keterlibatan ahli waris yang tidak mengetahui pelaksanaan pinjam emas dengan jaminan tanah sawah tersebut. Saran Disarankan kepada pihak-pihak atau lembaga adat yang terlibat dalam pembuatan surat keterangan gadai atau perjajian pinjam emas dengan jaminan tanah untuk membuat akta autentik. Akta autentik adalah suatu akta yang dibuat oleh atau dihadapan seorang penjabat umum yang berwenang untuk itu, seperti notaris, dimana bentuk aktanya ditentukan oleh undang-undang. Disarankan kepada pihak-pihak yang mengadakan perjanjian mengikuti tahaptahap dalam proses peminjaman dengan amanah dan jujur. Disarankan terhadap syarat sah perjanjian dilaksanakan sesuai ketentuan hukum yang berlaku dalam undang-undang yang berlaku. Disarankan kepada pemerintah kampung agar mengatur segala ketentuan-ketentuan gadai adat yang sudah terjadi turuntemurun dengan ketentuan Peraturan Desa. Mengingat perkembangan zaman sudah moderen maka penyelesaian sengketa bisa dilaksanakan dipengadilan atau pun menjalankan ketetapan-ketepan hukum yang telah ada. Hambatan tidak akan ada jika para pihak-pihak melaksanakan perjanjian dihadapan notaris karena bukti yang lengkap antara pihak dari ahli warisnya.

\section{DAFTAR PUSTAKA}

Ali, M. D. (2014). Hukum Islam. Jakarta: Raja Grafindo Persada.

Arifin, S. (2014). Pengantar Hukum Indonesia. Bandung: Citapustaka Media.

Kansil, C. (1986). Pengantar Ilmu Hukum dan Tata Hukum Indonesia. Jakarta: Balai Pustaka.

Muhammad, A. (1981). Hukum Perikatan. Bandung: Alumni.

Prodjodikoro, W. (2011). Azas-azas Hukum Perjanjian. Bandung: Mandar Maju.

Ruchyat, E. (1983). Pelaksanaan Landrefrom dan Jual Gadai Tanah Berdasarkan UU 
No. 56 ( Prp ) Tahun 1960. Bandung: Armico.

Salim, H. (2004). Perkembangan Hukum Jaminan. Jakarta: PT. Raja Grafindo Persada.

Soekanto, S. (2007). Sosiologi Suatu Pengantar. Jakarta: PT. Raja Grafindo Persada.

Soerjono Soekanto dan Sri Mamudji. (2001). Penelitian Hukum Normatif: Suatu Tinjauan Singkat. Jakarta: PT. Raja Grafindo Persada.

Soeroso, R. (1992). Pengantar Ilmu Hukum. Jakarta: Sinar Grafika.

Subekti, R. (2014). Aneka Perjanjian. Bandung: Citra Aditya Bakti.

Sunggono, B. (2011). Metodologi Penelitian Hukum. Jakarta: PT. Raja Grafindo Persada.

Supriadi. (2008). Hukum Agraria. Jakarta: Sinar Grafika.

Tutik, T. T. (2006). Pengantar Hukum Perdata Indonesia. Jakarta: Prestasi Pustaka Publisher.

Usman, R. (2016). Hukum Jaminan Keperdataan. Jakarta: Sinar Grafika. 